\title{
Treatment of patients with von Willebrand disease [Erratum]
}

Tuohy E, Litt E, Alikhan R. Journal of Blood Medicine 2011;2:49-57.

The reference column of Table 1 was incorrect in the published version. The correct Table 1, also amended for clarity, is below.

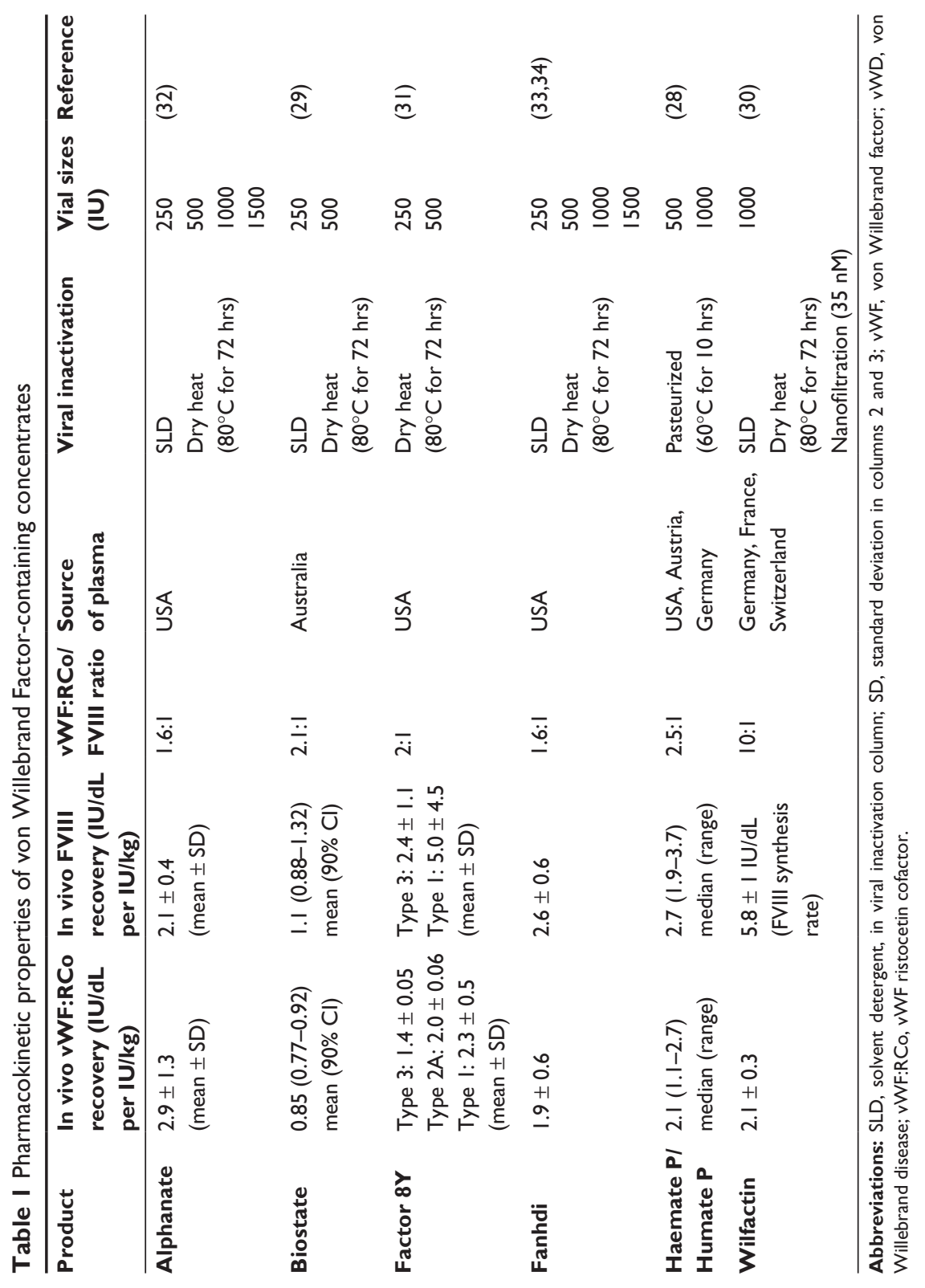


Journal of Blood Medicine

\section{Publish your work in this journal}

The Journal of Blood Medicine is an international, peer-reviewed, open access, online journal publishing laboratory, experimental and clinical aspects of all topics pertaining to blood based medicine including but not limited to: Transfusion Medicine; Blood collection, Donor issues, Transmittable diseases, and Blood banking logistics; Immunohematology; Artificial and alternative

Submit your manuscript here: http://www.dovepress.com/Journal-of-blood-medicine-journal

blood based therapeutics; Hematology; Biotechnology/nanotechnology of blood related medicine; Legal aspects of blood medicine; Historical perspectives. The manuscript management system is completely online and includes a very quick and fair peer-review system. Visit http://www.dovepress.com/ testimonials.php to read real quotes from published authors. 